\title{
IMPACT OF STOCKING DENSITIES, FERTILIZATION REGIME AND DIETARY PROTEIN LEVELS ON PRODUCTION AND PROFITABILITY OF MONOSEX NILE TILAPIA, OREOCHROMIS NILOTICUS, CULTURED IN PONDS
}

\author{
W.M.A. Fayed \\ Department of Animal and Fish Production, Faculty of Agriculture (Saba Basha), Alexandria \\ University, 22 Tag Al Roasaa st., saba-basha, boulkly, Alexandria, Egypt.
}

(Received 15/1/2015, accepted 3/3/2015)

\section{SUMMARY}

$\mathrm{T}$ The relationship between fertilization and dietary protein levels (20\%,25\% and 30\% crude protein) on growth, survival, body composition and upper limit of production were investigated for three different densities ( 5,10 and $15 \mathrm{fish} / \mathrm{m}^{3}$ ) of mono-sex Nile tilapia, Oreochromis niloticus, juveniles. The results showed that by increasing stocking density the growth performance significantly decreased $(\mathrm{P}<0.05)$, however, with fertilization this pattern demonstrated a positive relationship between density and final yield of $O$. niloticus juveniles with the increase of dietary protein level. Moreover, feed utilization and survival significantly increased $(\mathrm{P}<0.05)$ in fertilized ponds regardless to dietary protein levels. However, feed conversion ratio (FCR), protein productive value (PPV), and protein efficiency ratio (PER) significantly improved with applying fertilizers in ponds in all stocking densities. Meanwhile, when increasing dietary protein level the PPV and PER where significantly decreased $(\mathrm{P}<0.05)$. Consequently, with density $15 \mathrm{fish} / \mathrm{m}^{3}$ and $20 \%$ crude protein the FBW, WG, and ADG were significantly low with unfertilized ponds, while the opposite was observed with low density in fertilized ponds. In addition, the final total yield produced was significantly increased with the increase of fish density per cubic meter in the presence of fertilization, and increased insignificantly with the increase of dietary protein level. Thus, the economic assessment revealed that fertilization resulted in the possibility of using low dietary protein levels, and so increased the total outcome profit. Also, high density prompts the increased of total yield per feddan which resulted in a significant high profit return per capita. Finally, the present study advises using high stocking density per cubic meter with fertilized ponds and low dietary protein levels for $O$. niloticus juveniles.

Keywords: fertilization, dietary protein levels, growth performance, production, Oreochromis niloticus, density.

\section{INTRODUCTION}

Tilapia is ranked second only to carps in global production (Ridha, 2006). It is considered one of the fastest growing farming activities widely cultured in about 100 countries in the tropical and subtropical regions. Although, tilapia and salmon are the best fish species utilizing the protein in the diets, tilapia is more efficient in utilizing carbohydrates than lipids for energy production compared to other species. However, numerous factors as well as fish size, dietary protein source, energy content, water quality and culture conditions have been reported to affect protein requirements of tilapia (El-Saidy and Gaber, 2005). Tilapia can be raised in pond culture with the aid of inexpensive organic and inorganic fertilizers which increase pond productivity in terms of plankton production and which leads to greater fish production (Liti et al., 2002). Therefore, it is recommended that natural food should be applied during early growth stages, whereas supplemental feeds must be added at later stages (El-Sayed and Kawanna, 2008). Recently, focus has been given to use the economic levels of nutrients rather than the levels of dietary nutrients that maximize the growth. Moreover, feeding represents over $50 \%$ of the operational costs of aquaculture. Since protein is the main constituent of the fish body, so for optimum growth sufficient dietary supply is needed for optimum growth. Protein is the most expensive macronutrient in fish diet (Pillay, 1993). So, the amount of protein in the diet should be just enough for fish growth where the excess protein in fish diets may be wasteful and cause diets to be unnecessarily expensive (De Silva, 
2007). Therefore, economic evaluation of such protein sources for tilapia is necessary. The least cost dietary protein was recommended between 25 and 28\% CP. Diets containing 27 and 35\% crude protein have been found suitable for the growth of Nile tilapia reared in re-circulatory system. Tilapia broodstock require $35-45 \%$ dietary protein for optimum reproduction, spawning efficiency, and larval growth and survival (El-Sayed et al., 2003). Thus, reducing feeding costs could be a key factor for successful development of aquaculture. Fertilizers are used to reduce the quantity and expense of supplemental feeds. An increase in natural food has a much greater effect on tilapia production. Concurrently, reducing feeding rates either by delaying the introduction of feeds or by feeding less than the amount required for satiation had no effect on growth or yield of fish reared in fertilized ponds, that approach may be useful to reduce costs without compromising sales (Brown et al., 2002; Sallam 2010). In semi-intensive culture both fertilization and supplemental feeding would be more appropriate and cost-effective (El-Sayed, 2008). Since the male tilapia grows faster and reaches a larger size than the female, thus male batches are preferred in mono-sex culture. All-male tilapia cultures are often densely stocked. This will decrease the individual growth rate of each fish, but it will normally result in a higher yield per unit area. The full utilization of space for maximum fish production through intensive culture can improve profitability of fish production. Fish intensification by increasing stocking density is also found suitable to overcome the problem of land shortage (Khattab et al., 2004). Therefore, objectives of the present study is to maximize yield and profit per unit capitum by reducing cost through decreasing dietary protein levels of Nile tilapia, Oreochromis niloticus, juveniles using pond fertilization.

\section{MATERIALS AND METHODS}

\section{Experimental facilities and Fish species:}

The experimental trials for the present study were performed in 32 earthen ponds with area of $(20 \mathrm{~m}$ $\mathrm{x} 10 \mathrm{~m} \times 1 \mathrm{~m})$ for 210 days. Regular pre-stocking maintenance were performed on earthen ponds (completely drained, slope adjusted, exposed to sun, lime stone treated). Water exchange rate was designed to be $20 \%, 30 \%$, and $50 \%$ of the total water volume. Organic fertilizers (compost) were applied at a rate of $500 \mathrm{~kg} /$ feddan/week as applied in previous study performed by Sallam (2010). Each pond was continuously aerated with two mechanical pedals (2Hp each). Three commercial diets compositiin with crude protein levels $(20,25$ or $30 \% \mathrm{CP})$ are presented in Table 1. Fish were fed to satiation three times a daily six days a week. The treatments divided into three dietary protein levels of 20,25 or $30 \%$, each with and without organic fertilizer, and three stocking density levels $\left(5,10\right.$, and $\left.15 \mathrm{fish} / \mathrm{m}^{3}\right)$.

Sex-reversed male Nile Tilapia Male mono-sex Nile Tilapia fingerlings used were (29.4 $\mathrm{g} \pm 0.03)$ average body weight (BW). Water samples were analyzed and fish specimens were weighed monthly.

\section{Fertilizers:}

The organic fertilizer (compost) (Table 2) used during this study was obtained from the agricultural administration of Kafr Eldawar, Bahaira governorate, and applied at a rate of $500 \mathrm{~kg} / \mathrm{feddan} /$ week as performed by Sallam (2010). In addition, inorganic fertilizers as urea with nitrogen (N) content of $(46.5 \%)$ was added as source of nitrogen, and mono-super phosphate with phosphorus (P) content of $(15.5 \%)$ was added as a source of phosphorus. The amount of fertilizers were added weekly at a rate of 2.8 grams of $(\mathrm{N})$ and 0.7 grams of phosphorus $(\mathrm{P}) / \mathrm{m}^{2}$ to bring the ratio of $4: 1$ for $\mathrm{N}: \mathrm{P}$ (Yi and Lin., 2001).

Water samples were taken monthly for water quality analysis (temperature and dissolved oxygen DO $(\mathrm{mg} \backslash \mathrm{L})$ and $\mathrm{pH})$, along with fish weight. At the end of the experimental period fish were harvested, weighed and marketed to the closest market. Statistical and economic analyses were assessed thereafter.

Table (1): Chemical composition of three commercial diets used in the study

\begin{tabular}{lccc}
\hline \multirow{2}{*}{ Parameter } & \multicolumn{3}{c}{ Dietary protein levels $(\%)$} \\
\cline { 2 - 4 } & 20 & 25 & 30 \\
\hline Moisture & 9.20 & 9.16 & 9.00 \\
Crud protein & 18.88 & 24.81 & 29.73 \\
Crude fat & 8.98 & 8.21 & 7.60 \\
Ash & 7.62 & 8.50 & 8.00 \\
\hline
\end{tabular}


Egyptian J. Nutrition and Feeds (2015)

Table (2): Chemical analysis of organic fertilizer (compost) used in the present study.

\begin{tabular}{ll}
\hline Parameter & Value (\%) \\
\hline Moisture content & 9.80 \\
Nitrogen & 1.74 \\
Phosphorus & 0.85 \\
Organic matter (carbon) & 63.55 \\
\hline
\end{tabular}

\section{Analytical methods:}

All chemical analysis was determined according to the methods described by the American Public Health Association (APHA, 1998). Total ammonia $(\mathrm{mglL})$ concentration was determined by nesslerization method according to the following equation (Boyd, 1990):

$$
\mathrm{NH}_{3}=\mathrm{A} \backslash 100 \times 1.2 \times \text { total ammonia }
$$

Where, (A) is an appropriate factor related to water $\mathrm{pH}$ and temperature at the time of testing. Total phosphorus and orthophosphate $(\mathrm{mg} / \mathrm{L})$ concentration was determined in samples using spectrophotometer at 880nm (Boyd and Tucker, 1998).

\section{Growth performance and Feed utilization:}

Feed conversion ratio (FCR), protein efficiency ratio (PER), protein productive value (PPV \%), were calculated from their chemical composition using the factor of 5.7 and 9.5 for protein and fat, respectively according to (NRC, 1993). However, growth performance and feed utilization parameters were measured and calculated according to Xie et al., (1997) and Dato-Cajegas and Yakupitiyage (1996):

Weight gain $(\mathrm{WG})=$ final weight - initial weight .

Average daily gain $(\mathrm{ADG})=($ final weight - initial weight $) /$ number of days .

FCR =dry matter feed intake/ gain.

$\mathrm{PER}=$ gain/protein intake.

PPV\%=protein increment (100)/protein intake.

\section{Statistical analysis:}

Data was subjected to one way analysis of variance (ANOVA) using the Sigmastat 2.5 (Statistical package for social science) software. Differences between means parameters were analyzed using Duncan Multiple Range Test at $1 \%$ level of significance.

\section{Economical evaluation:}

A comparative economic evaluation throughout the experiment was conducted as described by Ita and Okeoye (1988). The following parameters were used: fixed costs, variable costs, total return, total income, operating ratio, return on sales, and return on costs. The economic assessment indicators were used such as: operating ratio, which is considered one of the indicators of economical efficiency for the farm in using its resources. The return on sales, which is considered on of the fish farm administrative efficiency ( 1 minus operating ratio) and reflect the fish farm capability to face the fish risks of low price or increase of costs of selling (total income/total cost). The return on costs is an indicator for economic surplus of the fish farm (investment cost/ total income).

\section{RESULTS AND DISCUSSION}

The survival percentage and growth performance of the $O$. niloticus juveniles proceeded in a linear fashion throughout the present study. Overall survival percentage differed significantly $(\mathrm{P}<0.01)$ for the three stocking densities. The low density $(5 \mathrm{fish} / \mathrm{m} 3)$ had a significant $(\mathrm{P}<0.01)$ higher survival percentage than the intermediate $(10 \mathrm{fish} / \mathrm{m} 3)$ and high $(15 \mathrm{fish} / \mathrm{m} 3)$ density. However, with the increase of dietary protein level a significant $(\mathrm{P}<0.01)$ increase in survival percentage was observed, especially for $20 \%$ and $25 \%$ dietary protein levels. Similar pattern was noticed in fertilized ponds versus unfertilized ponds (Table 3). Fertilized ponds was significantly higher $(\mathrm{P}<0.01)$ in survival percentage than unfertilized ponds regardless of stocking density and dietary protein levels.

Although, the interaction between stocking density, dietary protein levels and fertilization for survival of O. niloticus demonstrated a significant $(\mathrm{P}<0.01)$ high percentage $(90.5 \%)$ for treatments received $30 \%$ $\mathrm{CP}$ with low stocking density in fertilized ponds. Consequently, treatments with $25 \% \mathrm{CP}$ in the 
intermediate stocking density in fertilized ponds trailed the former mentioned treatment with percentage of $(86.5 \%)$. Similar trend was observed in treatments with $25 \% \mathrm{CP}$ in the high stocking density and fertilized ponds with percentage of $(71.5 \%)$. On the other hand, the lowest survival percentage was observed for the high stocking density and low protein level and unfertilized ponds (65.5\%). Stocking density is one of the major factors in aquaculture directly influencing growth, survival rate, health, feeding and production of fish under farmed conditions (Rahman et al., 2003). In the present study, significantly $(\mathrm{P}<0.01)$ highest survival rate for $O$. niloticus was realized at the lowest stocking density. This result is in conformity with findings of previous researchers (Vera Cruz and Mair, 1994 ; Suman and Samir, 2010) who reported higher survival rate at the lowest stocking density. They also pronounced that fish survival decreased as stocking density increased due to cannibalism, poor handling, stress and severe competition for food and space. In addition, a report by (Osofero et al., 2009) in a study on the effects of stocking density on growth and survival of $O$. niloticus, they found out an inverse relationship between survival rate and stocking density.

Similarly, growth rate demonstrated by final body weight (FBW), body gain (BG), average daily gain $(A D G)$ differed significantly $(\mathrm{P}<0.01)$ among treatments with the increase of dietary protein levels and presence of fertilization in ponds and decrease of stocking density (Table 3). In low and intermediate stocking densities the FBW (323and 317g/fish), BG (294 and 287g/fish) and ADG (1.4 and $1.37 \mathrm{~g} /$ fish/day) were significantly $(\mathrm{P}<0.01)$ higher than that of high stocking density $(293 \mathrm{~g} /$ fish; $266 \mathrm{~g} / \mathrm{fish} ; 1.27 \mathrm{~g} / \mathrm{fish} /$ day), respectively. Additionally, growth rate represented by FBW, BG, and ADG increased significantly $(\mathrm{P}<0.01)$ with the increase of dietary protein levels and presence of fertilization in ponds and decrease of stocking density (Table 3). In low and intermediate stocking densities the FBW, $\mathrm{BG}$ and $\mathrm{ADG}$ were significantly $(\mathrm{P}<0.01)$ higher than that of high stocking density. The observed decrease growth rate with increasing stocking density in this study corresponds to observation also reported by (Ferdous et al., 2014). Yi and Lin (2002) obtained a higher ADG for tilapia of an initial weight of $33.2 \mathrm{~g}$ which consumed food containing $30 \%$ protein in addition to fertilization. Also, Kheir and Saad, (2003) proved that the least stocking rate attained the highest final weight, weight gain, feed conversion, and protein efficiency ratio for $O$. niloticus. The lower growth performance of tilapia at higher stocking density could have been caused by voluntary appetite suppression, more expenditure of energy because of antagonistic behavioral interaction, competition for food and living space (Diana et al., 2004) and increased stress (Ouattara et al., 2003).

However, feed conversion ratio (FCR) was improved significantly $(\mathrm{P}<0.05)$ with the presence of fertilization, and with the increase of dietary protein levels and decrease of stocking density. Whereas, low and intermediate stocking densities were significantly $(\mathrm{P}<0.05)$ enhanced than high stocking density with FCR values of 1.50, 1.49 and 1.62, respectively. In the present study, FCR value ranged from 1.50 to 1.62. Low stocking density showed the least FCR value, which could be attributed to effective feed utilization which reflected in the growth of fish. Increase in FCR with increasing stocking density is in agreement with results obtained by (Gibtan et al., 2008). On the contrary, Kapinga et al. (2014) reported that FCR showed no significant difference with stocking densities. However, Siddiqui et al. (1989) reported no difference on the FCR value of $O$. niloticus reared in brackish water at densities of 16, 32 and 42.6 fish per tank.

The protein efficiency ratio (PER) and percentage of protein productive value (PPV \%) were highly correlated with pond fertilization recording of 2.92 and $49.79 \%$, respectively (Table 3 ). Although, these observed results were significantly $(\mathrm{P}<0.05)$ higher for fertilized ponds versus unfertilized pond, but with dietary protein levels and stocking densities a negative correlation was detected. The present study results corresponds with results reported by Bahnasawy (2009) where his results showed that PER is significantly affected by protein levels and manifests that protein utilization was obtained at low protein level.

However, the final total yield/feddan increased significantly $(\mathrm{P}<0.05)$ with the increase of stocking densities and in the presence of fertilization, with total yield of 10,927, 9,271 and 5,517 kg/feddan for high, intermediate and low stocking densities, respectively. In addition, the total yield in fertilized ponds expressed a similar pattern as stocking density, where fertilized ponds produced a significantly higher yield $(\mathrm{P}<0.05)$ than unfertilized ponds with 9,377 kg/feddan and 7,899 kg/feddan, respectively. Moreover, dietary protein levels demonstrated a significant high $(\mathrm{P}<0.05)$ yield for treatments with $25 \%$ and $30 \% \mathrm{CP}$. Whereas, treatments with the $20 \% \mathrm{CP}$ did not differ significantly $(\mathrm{P}>0.05)$ than treatments with $30 \% \mathrm{CP}$ (Table 3). The present study results reported higher yield/feddan than those reported by Bahnasawy et al. (2003) and Yi and Lin (2002) for Nile tilapia reared in fertilized earthen ponds. The higher fish production which in the present study may be attributed to both the high productivity and abundance of natural food induced by phosphate and urea fertilizers as reported by Dato-Cajegas and Yakupitiyage (1996). 
Throughout the experimental period, the overall temperature ranged from $24^{\circ} \mathrm{C}$ to $32^{\circ} \mathrm{C}$ with an average of $28 \pm 2.89^{\circ} \mathrm{C}$. The dissolved oxygen (DO) fluctuated within the treatments of the present study with no significant differences (Table 4). It was as high as $8.17 \mathrm{mg} \mathrm{L}^{-1}$ for low density and low dietary protein level for the first month (April). It decreased gradually throughout the period of the experiment reaching its lowest level of $2.68 \mathrm{mg} \mathrm{L}-1$ for intermediate density, 30\% CP and unfertilized pond treatment in the month of August, then increased insignificantly by the end of experimental period (5.94 mg L-1; low density, fertilized and $20 \% \mathrm{CP}$ ). Correspondingly, previous researches reported that Tilapia has a low oxygen demand and can survive at low oxygen levels (Siddiqui et al., 1989).

The total ammonia (TA) and un-ionized ammonia (UA) showed significant differences $(\mathrm{P}<0.05)$ among treatments. The TA and UA correlated significantly with stocking density, reporting 1.107 and $0.405 \mathrm{mg} \mathrm{L}^{-1}$, respectively with high stocking density (Table 4). However, the UA increased significantly $(\mathrm{P}<0.05)$ in unfertilized ponds compared to fertilized $\left(0.340-0.336 \mathrm{mg} \mathrm{L}^{-1}\right)$. Additionally, the dietary protein level had a significant $(\mathrm{P}<0.05)$ effect on TA and not on UA, where TA decreased significantly with the increase of dietary protein level. Consequently, the UA correlated insignificantly with dietary protein level (Table 4). Total phosphorus (TP) and orthophosphate (OP) decreased insignificantly with the increase in stocking density, and increased significantly $(\mathrm{P}<0.05)$ with the application of fertilizers in ponds. As for dietary protein levels, the TP and OP was insignificantly high with $20 \%$ and $30 \%$ CP with values of $0.989 ; 0.554 \mathrm{mg} \mathrm{L}^{-1}$ and $1.375 ; 0.634 \mathrm{mg} \mathrm{L}^{-1}$, respectively (Table 4).

The economic analysis indicated that the grow outs or net income at 15 fish $\mathrm{m}^{-3}$ (EGP 77,750 feddan $\left.{ }^{1}\right)$ were significantly $(\mathrm{P}<0.01)$ profitable than intermediate (EGP 66,417 feddan ${ }^{-1}$ ) and low (EGP 39,144 feddan $\left.^{-1}\right)$ stocking densities. The results of the operating ratio $(\mathrm{OR} \%)$ significantly $(\mathrm{P}<0.01)$ increases with stocking density, on the contrary, the return on cost $(\mathrm{RC} \%)$ significantly $(\mathrm{P}<0.01)$ decreases with high stocking density. However, the net income for fertilized was significantly higher $(\mathrm{P}<0.01)$ than unfertilized ponds (EGP 70,846 versus 51,361 feddan-1), respectively (Table 5). Similarly, the net income, RC\% and RS\% significantly decreased $(\mathrm{P}<0.01)$ with the increase of dietary protein level from $20 \%$ to $30 \% \mathrm{CP}$, recording the highest return for $20 \% \mathrm{CP}$ (EGP 62,852 feddan $^{-1}$ ). Thus, the OR\% significantly increased $(\mathrm{P}<0.01)$ with $30 \% \mathrm{CP}$ due to high value cost of protein level diets.

\section{CONCLUSION}

By using fertilization, dietary protein levels could be reduced without significantly reducing growth rate and performance. Increasing density with fertilization and low dietary protein level, gives high net income per unit. Thus, we recommend using fertilization with high fish density ( $15 \mathrm{fish} / \mathrm{m} 3)$, and reducing dietary protein level $(20 \% \mathrm{CP})$, to reduce cost production of Nile Tilapia and increases the income.

\section{ACKNOWLEDGMENT}

The author would like to acknowledge Dr. Sallam, G.R., (Associate Professor, National Institute of Oceanography and Fisheries, Egypt) for collaboration and unconditional support in the present study research.

\section{REFERENCES}

APHA. (1998). Standard Methods for the Examination of Water and Wastewater. 20th edn. APHA (American Public Health Association), Washington, USA.

Bahnasawy M.H. (2009). Effect of Dietary Protein Levels on Growth Performance and Body Composition of Monosex Nile Tilapia, Oreochromis niloticus L. Reared in Fertilized Tanks. Pak. J. of Nutrition 8 (5): 674-678.

Bahnasawy, M.H.; E.A. Taman and A.A. Gamal. (2003). Growth performance of Nile tilapia (Oreochromis niloticus) fingerlings raised in an earthen pond. Arch. of Pol. Fish. 


\section{Fayed}

Boyd, C.E. (1990). Water Quality in ponds for Aquaculture. Alabama Agricultural Experiment Station, Auburn University, Auburn, Alabama, 482 pp. Boyd, C.E. (1995). Bottom Soil, Sediment, and Pond Aquaculture. Chapman and Hall, New York.

Boyd, C.E. and C.S. Tucker (1998). Water quality requirements. Pond aquaculture water quality management, 87-153.

Brown, C.; R. Bolivar; E. Jimenez and J. Szyper (2002). Reduction of feed rations below satiation levels in tilapia pond production. In: K. McElwee, K. Lewis, M.Nidiffer and P. Buitrago (Eds.). Nineteenth Annual Technical Report. Pond Dynamics /Aquaculture CRSP, Oregon State University, Corvallis, Oregon, pp. 21-23.

Dato-Cajegas, C.R. and A. Yakupitiyage (1996). The need for dietary mineral supplementation for Nile tilapia, Oreochromis niloticus, cultured in a semi-intensive system. Aquaculture, 144(1-3): 227-237.

De Silva, S.S. (2007). Reducing feed costs through adoption of mixed feeding schedule practices in semiintensive aquaculture. Int. Aqua Feed, 10(5): 18-22.

El-Saidy, D.M.S.D. and M.M.A. Gaber (2005). Effect of dietary protein levels and feeding rates on growth performance, production traits and body composition of Nile tilapia, Oreochromis niloticus (L.) cultured in concrete tanks. Aquaculture Research, 36: 163-171.

El-Sayed, A.F.M. (2008). Reducing feed costs in semi-intensive tilapia culture. Int. Aqua feed, 11 (1): $32-$ 34.

El-Sayed, A.F.M. and M. Kawanna (2008). Effects of dietary protein and energy levels on spawning performance of Nile tilapia (Oreochromis niloticus) broodstock in a recycling system. Aquaculture, 280: $179-184$.

El-Sayed, A.F.M.; C.R. Mansour and A.A. Ezzat (2003). Effects of dietary protein levels on spawning performance of Nile tilapia (Oreochromis niloticus) broodstock reared at different water salinities. Aquaculture, 220: 619-632.

Ferdous, Z.; A. Masum and M. Ali (2014). Influence of Stocking Density on Growth Performance and Survival of Monosex Tilapia (Oreochromis niloticus) Fry. Int. J. of Res. in Fish. and Aqua., 4(2): 99103.

Fotedar, R. (2004). Effect of dietary protein and lipid source on the growth, survival, condition indices and body composition of marron, Cherax tenuimanus (Smith). Aquacult., 230: 439-455.

Gibtan, A.; A. Getahun; S. Mengistou (2008). Effect of stocking density on the growth performance and yield of Nile tilapia (O. niloticus, L.) in a cage culture system in Lake Kuriftu, Ethopia, Aquacult. Res. 39: $1450-1460$.

International Symposium on Tilapia in Aquaculture, R. Bolivar, G. Mair and K. Fitzsimmons, Eds. Manila, Philippines, BFAR, Philippines, pp. 264-276.

Ita, E.O. and C. Okeoye (1988). Preliminary comparison of the growth performance of all-male, all female and mixed population of Oreochromis niloticus in hapa net in fertilized concrete ponds. National Institute for Freshwater Fisheries Research. Annual Report, 1988.

Kapinga, I.; E. Mlaponi and N. Kasozi (2014). Effect of Stocking Density on the Growth Performance of Sex Reversed Male Nile Tilapia (Oreochromis niloticus) Under Pond Conditions in Tanzania. W. J. of Fish and Marine Sci., 6 (2): 156-161.

Khattab, Y. A. R.; M. Abdel-Tawwab and M.H. Ahmad (2004). Effect of protein level and stocking density on growth performance, survival rate, feed utilization and body composition of Nile tilapia fry (Oreochromis niloticus L.), in Proceedings of the Sixth.

Kheir, M.T. and A.S. Saad (2003). Growth performance and feed utilization of Oreochromis niloticus (Linnaeus, 1757) fingerlings as affected with stocking density and feeding regime. J. Egypt. Acad. Soc. Environ. Develop., (B-Aquaculture), 4 (2): 1-21. landlocked and natural populations under cage culture conditions in Lake Ayame (Cote d'Ivoire). Aquaculture Research 34(13): 1223-1229.

Liti D.H.; O.E. Mac-Were; K.L. Veverica (2002). Growth performance and economic benefits of Oreochromis niloticus/Clarias gariepinus polyculture fed on three supplementary feeds in fertilized tropical ponds - Nineteenth Annual Technical Report. Pond Dynamics/Aquaculture CRSP, Oregon State University, Corvallis, Oregon: 11-16.

NRC (1993). Nutrient Requirements of Fish. National Academy Press, Washington, DC, 114 pp.

Osofero, S.A.; S.O. Otubusin; J.A. Daramola (2009). Effect of stocking density on tilapia (Oreochromis niloticus, Linnaeus 1757) growth and survival in bamboo-net cages trial, Afr. J. Biotechnolo. 8: 13221325 . 
Ouattara, N.I.; G.G. Teugels; V.N. Douba and J.C. Philippart (2003). Aquaculture potential of the blackchinned tilapia, Sarotherodon melanotheron (Chiclidae). Comparative study of the effect of stocking density on growth performance of landlocked and natural populations under cage culture conditions in Lake Ayame (Cote d'Ivoire). Aquaculture Research, 32: 1223-1229

Pillay, T.V.R. (1993). Aquaculture. Principles and Practices. Blackwell, Oxford, 575 pp.

Rahman, M.R. and M.A. Rahman (2003). Studies on the growth, survival and production of calbasu (Labeo calbaus Ham.) at different stocking densities in primary nursing, Bull. Fac. Sci. Unv. Ryuyus. Jpn., 76: 245-255.

Ridha, M.T. (2006). Comparative study of growth performance of three strains of Nile tilapia, Oreochromis niloticus, L. at two stocking densities. Aquaculture Research, 37: 172-179.

Sallam, G.R. (2010). Studies on production and spawning of Oreochromis sp. PhD Dissertation, Alexandria University, 245pp.

Siddiqui, A.Q.; M.S. Howlader; A.B. Adam (1989). Culture of Nile tilapia (Oreochromis niloticus, L.) at three stocking densities in outdoor concrete tanks using drainage water, Aquacult. Fish. Manage., 20, 49-57.

Suman, B.C. and B. Samir (2010). Effect of stocking density on Mono-sex Nile Tilapia growth during pond culture in India, W. Aca. Sci. Eng. Technol., 68: 20-26.

Vera Cruz, E.M. and G.C. Mair (1994). Conditions for effective androgen sex reversal in Oreochromis niloticus (L.), Aquaculture, 112, 137-248.

Xie, S.; Y. Cui; Y. Yang and J. Liu (1997). Effect of body size on growth and energy budget of Nile tilapia Oreochromis niloticus. Aquacult., 157:25-34.

Yi, Y. and C.K. Lin. (2001). Effects of biomass of caged Nile tilapia (Oreochromis niloticus) and aeration on the growth and yields in an integrated cage-cum-pond system. Aquaculture, 195:253-267. 
Table (4): Water quality analysis of the parameters; dissolved oxygen (DO), Total ammonia (TA), Total phosphorus (TP), un-ionized ammonia (UA), and Orthophosphate (OP), in mg $\mathrm{L}^{-1}$ measured in the present study

\begin{tabular}{cccccccc}
\hline Density & Fertilization & CP\% & DO & TA & TP & UN & OP \\
\hline 5 & & & $5.931 \pm 0.50$ & $0.794 \pm 0.04^{\mathrm{b}}$ & $1.126 \pm 0.63$ & $0.298 \pm 0.01^{\mathrm{b}}$ & $0.609 \pm 0.02$ \\
10 & & & $5.248 \pm 0.49$ & $0.811 \pm 0.03^{\mathrm{b}}$ & $1.070 \pm 0.66$ & $0.313 \pm 0.02^{\mathrm{b}}$ & $0.491 \pm 0.01$ \\
15 & & & $5.055 \pm 0.33$ & $1.107 \pm 0.04^{\mathrm{a}}$ & $0.639 \pm 0.77$ & $0.405 \pm 0.02^{\mathrm{a}}$ & $0.348 \pm 0.01$ \\
& $\mathrm{U}$ & & $5.630 \pm 055$ & $0.806 \pm 0.04$ & $0.876 \pm 0.23^{\mathrm{b}}$ & $0.340 \pm 0.01^{\mathrm{a}}$ & $0.437 \pm 0.02^{\mathrm{b}}$ \\
& $\mathrm{F}$ & & $5.547 \pm 0.44$ & $0.910 \pm 0.05$ & $0.970 \pm 0.22^{\mathrm{a}}$ & $0.336 \pm 0.01^{\mathrm{b}}$ & $0.458 \pm 0.01^{\mathrm{a}}$ \\
& & 20 & $5.057 \pm 0.57$ & $0.997 \pm 0.02^{\mathrm{a}}$ & $0.989 \pm 0.3$ & $0.340 \pm 0.02$ & $0.554 \pm 0.01$ \\
& & 25 & $5.135 \pm 0.56$ & $0.912 \pm 0.04^{\mathrm{b}}$ & $0.516 \pm 0.11$ & $0.289 \pm 0.01$ & $0.331 \pm 0.02$ \\
& & 30 & $5.689 \pm 0.60$ & $0.897 \pm 0.02^{\mathrm{c}}$ & $1.375 \pm 0.11$ & $0.388 \pm 0.02$ & $0.634 \pm 0.02$ \\
\hline
\end{tabular}

Table (5): Total cost (TC), Total income (TI), Net income (NI) in Egyptian pounds/feddan, Operating ratio (OR \%), Return on cost (RC \%), and Return on sale (RS \%) assessed for

\begin{tabular}{|c|c|c|c|c|c|c|c|c|}
\hline $\mathrm{D}$ & $\mathrm{F}$ & $\mathrm{CP} \%$ & TC & TI & $\mathrm{NI}$ & OR\% & $\mathrm{RC} \%$ & $\mathrm{RS} \%$ \\
\hline \multirow{7}{*}{5} & \multirow{3}{*}{$\mathrm{U}$} & 20 & $24,086^{\mathrm{g}}$ & $57,984^{i}$ & $33,898^{j}$ & $41.54^{\mathrm{c}}$ & $240.74^{\mathrm{d}}$ & $58.46^{\mathrm{ab}}$ \\
\hline & & 25 & $31,488^{f}$ & $67,128^{\mathrm{hi}}$ & $35,639^{\mathrm{ij}}$ & $46.91^{\mathrm{b}}$ & $213.18^{f}$ & $53.09^{\text {bd }}$ \\
\hline & & 30 & $32,133^{\mathrm{f}}$ & $69,544^{\mathrm{hi}}$ & $37,411^{\mathrm{i}}$ & $46.21^{b}$ & $216.42^{f}$ & $53.79^{b c}$ \\
\hline & \multirow{4}{*}{$\mathrm{F}$} & 20 & 22,846 & $66,408^{i}$ & $43,561^{\mathrm{h}}$ & $34.40^{c}$ & $290.67^{a}$ & $65.60^{\mathrm{a}}$ \\
\hline & & 25 & $28,140^{\mathrm{fg}}$ & $70,858^{\mathrm{h}}$ & $42,718^{\mathrm{h}}$ & $39.71^{b c}$ & $251.81^{b}$ & $60.29^{\mathrm{ab}}$ \\
\hline & & 30 & $30,941^{\mathrm{f}}$ & $72,575^{\mathrm{h}}$ & $41,633^{\mathrm{hi}}$ & $42.63^{c}$ & $234.56^{\mathrm{d}}$ & $57.37^{\mathrm{b}}$ \\
\hline & & 20 & $47,134^{\mathrm{e}}$ & $102,297^{\mathrm{g}}$ & $55,163^{\mathrm{fg}}$ & $46.08^{b}$ & $217.04^{\mathrm{f}}$ & $53.92^{\mathrm{bc}}$ \\
\hline \multirow{7}{*}{10} & \multirow[t]{3}{*}{$\mathrm{U}$} & 25 & $56,007^{\mathrm{cd}}$ & $114,260^{\mathrm{f}}$ & $58,253^{\mathrm{f}}$ & $49.02^{\mathrm{b}}$ & $204.01^{\mathrm{g}}$ & $50.98^{\mathrm{c}}$ \\
\hline & & 30 & $59,652^{\mathrm{c}}$ & $112,132^{\mathrm{f}}$ & $52,480^{\mathrm{g}}$ & $53.20^{\mathrm{a}}$ & $187.98^{\mathrm{h}}$ & $46.80^{c}$ \\
\hline & & 20 & $43,587^{\mathrm{e}}$ & $123,191^{\mathrm{e}}$ & $79,604^{b}$ & $35.38^{c}$ & $282.63^{a}$ & $64.62^{\mathrm{a}}$ \\
\hline & \multirow[t]{3}{*}{$\mathrm{F}$} & 25 & $52,609^{d}$ & $134,592^{\mathrm{d}}$ & $81,984^{\mathrm{b}}$ & $39.09^{c}$ & $255.84^{\mathrm{c}}$ & $60.91^{\mathrm{ab}}$ \\
\hline & & 30 & $60,326^{\mathrm{c}}$ & $131,341^{\mathrm{d}}$ & $71,015^{\mathrm{c}}$ & $45.93^{b}$ & $217.72^{f}$ & $54.07^{\mathrm{b}}$ \\
\hline & & 20 & $76,714^{b}$ & $141,619^{c}$ & $64,905^{\mathrm{d}}$ & $54.17^{\mathrm{a}}$ & $184.61^{\mathrm{h}}$ & $45.83^{\mathrm{cd}}$ \\
\hline & $\mathrm{U}$ & 25 & $85,926^{\mathrm{a}}$ & $149,362^{b}$ & $63,436^{\mathrm{de}}$ & $57.53^{a}$ & $173.83^{\mathrm{i}}$ & $42.47^{\mathrm{d}}$ \\
\hline \multirow{4}{*}{15} & & 30 & $89,279^{\mathrm{a}}$ & $150,341^{b}$ & $61,062^{\mathrm{e}}$ & $59.38^{a}$ & $168.39^{j}$ & $40.62^{\mathrm{d}}$ \\
\hline & & 20 & $61,711^{\mathrm{c}}$ & $161,689^{\mathrm{a}}$ & $99,979^{\mathrm{a}}$ & 38.17 & $262.01^{b}$ & $61.83^{\mathrm{a}}$ \\
\hline & \multirow[t]{2}{*}{$\mathrm{F}$} & 25 & $75,379^{b}$ & $169,890^{\mathrm{a}}$ & $94,510^{\mathrm{a}}$ & $44.37^{b}$ & $225.38^{e}$ & $55.63^{\mathrm{b}}$ \\
\hline & & 30 & $82,685^{\mathrm{a}}$ & $165,290^{\mathrm{ab}}$ & 82,606 & $50.02^{b}$ & $199.90^{\mathrm{fg}}$ & $49.98^{\mathrm{cd}}$ \\
\hline 5 & \multirow{8}{*}{$\begin{array}{l}\mathrm{U} \\
\mathrm{F}\end{array}$} & & $28,272^{\mathrm{c}}$ & $67,416^{c}$ & $39,144^{\mathrm{c}}$ & $42^{c}$ & $241^{\mathrm{a}}$ & $58^{\mathrm{a}}$ \\
\hline 10 & & & $53,219^{b}$ & $119,636^{b}$ & $66,417^{\mathrm{b}}$ & $45^{\mathrm{b}}$ & $228^{\mathrm{b}}$ & $55^{\mathrm{b}}$ \\
\hline \multirow[t]{6}{*}{15} & & & $78,615^{\mathrm{a}}$ & $156,365^{\mathrm{a}}$ & $77,750^{\mathrm{a}}$ & $51^{\mathrm{a}}$ & $202^{c}$ & $49^{c}$ \\
\hline & & & $55,824^{\mathrm{a}}$ & $107,185^{b}$ & $51,361^{\mathrm{b}}$ & $50^{\mathrm{a}}$ & $201^{\mathrm{b}}$ & $50^{\mathrm{b}}$ \\
\hline & & & $50,914^{\mathrm{b}}$ & $121,759^{\mathrm{a}}$ & $70,846^{\mathrm{a}}$ & $41^{\mathrm{b}}$ & $247^{\mathrm{a}}$ & $59^{a}$ \\
\hline & & $20 \% \mathrm{CP}$ & $46,013^{c}$ & $108,865^{b}$ & $62,852^{\mathrm{a}}$ & $42^{c}$ & $246^{\mathrm{a}}$ & $58^{\mathrm{a}}$ \\
\hline & & $25 \% \mathrm{CP}$ & $54,925^{b}$ & $117,682^{\mathrm{a}}$ & $62,757^{\mathrm{a}}$ & $46^{\mathrm{b}}$ & $221^{b}$ & $54^{\mathrm{b}}$ \\
\hline & & $30 \% \mathrm{CP}$ & $59,169^{a}$ & $116,870^{\mathrm{a}}$ & $57,701^{b}$ & $50^{\mathrm{a}}$ & $204^{c}$ & $50^{c}$ \\
\hline
\end{tabular}


Egyptian J. Nutrition and Feeds (2015) 


\title{
Fayed
}

\section{تأثير الكثافه والتسميا ومستويات البروتين فى علاثق أسماك البلطى النيلى أحادى الجنس المرباه فى أحواض ترابيه على إنتاجيه الفدان وأثر ذلك إقتصاديا}

\author{
وليد محمد عبد الوهاب محمد فايد \\ قسم الإتتج الحيو انى و السمكى, كليه زراعة سابا باثا, جامعة الإسكندريه, ج. م.ع
}

أجريت هذه التجربه فى إحدى مزارع القطاع الخاص بمنطقة إدكو محافظة البحيره بهدف رفع مستوى إنتاجيه الفدان من أسماك البطى البطى

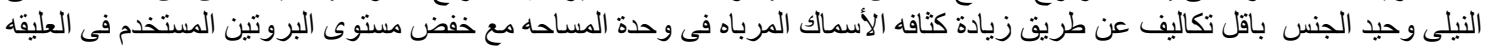

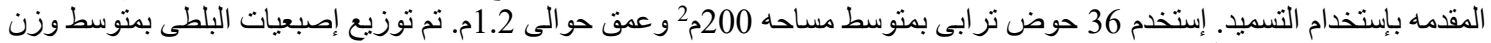

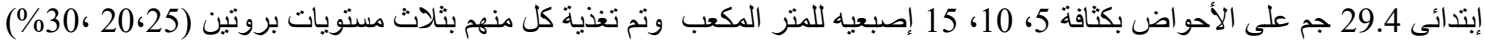

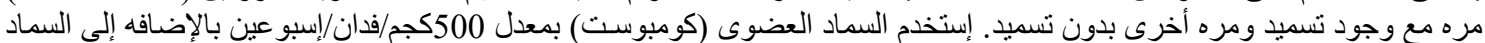

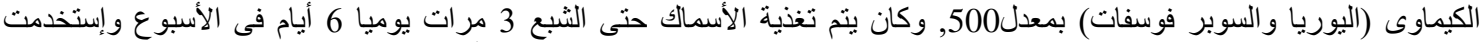

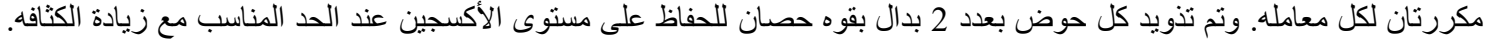

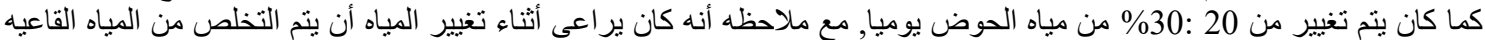

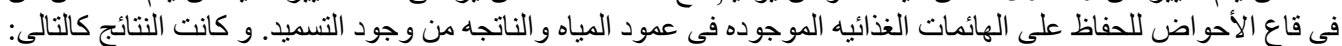

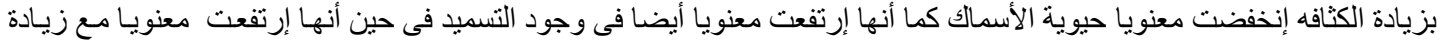

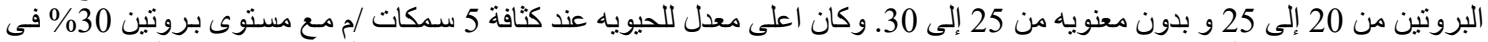

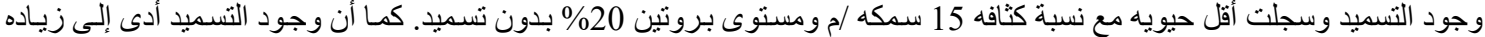

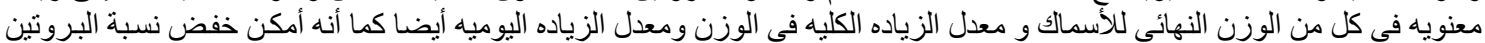

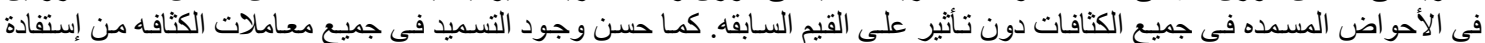

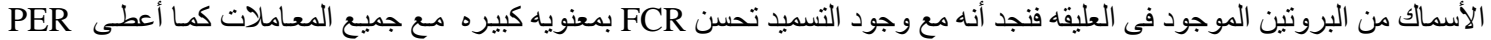

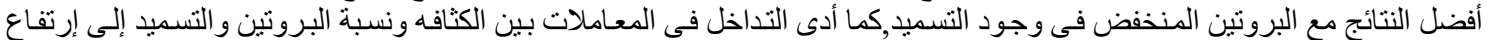

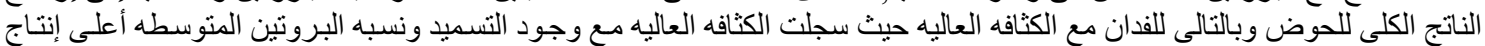

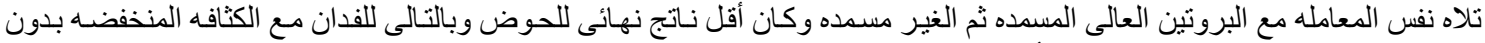

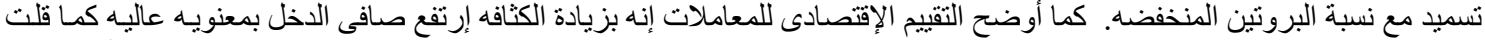

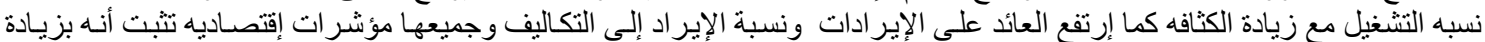

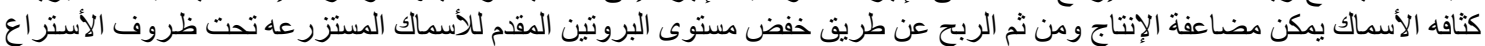
المكثف عن طريق التسميد. 